Research Article

\title{
Three Species of Genus Lepisiota (Hymenoptera: Formicidae) with New Distributional Records from Khyber Pakhtunkhwa, Pakistan
}

\author{
Kiran Shahjeer $^{1 *}$, Gauhar Rehman ${ }^{1}$, Khurshaid Khan ${ }^{1}$ and Toheed Iqbal ${ }^{2}$ \\ ${ }^{1}$ Department of Zoology, Abdul Wali Khan University, Mardan, Khyber Pakhtunkbwa, Pakistan; ${ }^{2}$ Department of Entomology, \\ University of Agriculture, Peshawar, Khyber Pakhtunkhwa, Pakistan.
}

Abstract | A study on the ant fauna of north-western part comprising of the hilly colder mountains in the
North to the Dry hot plains in the South of Khyber Pakhtunkhwa province of Pakistan was conducted during
2017-2020. Area was surveyed and collection of worker ants from the area was hired by using pitfall traps,
aspirator and hand picking with the help of forceps. The study revealed that three species belonging to genus
Lepisiota as a major outcome of this taxonomic study. The species include L. frauenfeldi, L. simplex, L. opaca and
its sub-species L. o. pulchella. Among them two species viz., L. simplex, L. opaca and a subspecies of L. opaca i.e.
L. o. pulchella are reported as first distributional records from Khyber Pakhtunkhwa. Keys to the subfamilies
of Family Formicidae and worker caste species of genus Lepisiota collected from Khyber Pakhtunkhwa along
with its spatial distributional map for all species and a sub-species is provided. All the specimen are deposited
at Insect Museum, Department of Zoology, Abdul Wali Khan University Mardan, Pakistan. From the study,
it is concluded that the fauna of Khyber Pakhtunkhwa is rich in ant species. Species diversity and abundance
are expected more diverse collections in these and other similar areas. These findings can be strengthened by
modern techniques of molecular identification.
Received | January 06,2021; Accepted | April 20,2021; Published | July 01, 2021
*Correspondence | Kiran Shahjeer, Department of Zoology, Abdul Wali Khan University, Mardan, Khyber Pakhtunkhwa, Pakistan; Email:
Kiranshahjeer@awkum.edu.pk
Citation | Shahjeer, K., G. Rehman, K. Khan and T. Iqbal. 2021. Three species of Genus Lepisiota (Hymenoptera: Formicidae) with new
distributional records from Khyber Pakhtunkhwa, Pakistan. Sarbad Journal of Agriculture, 37(3): 884-892.
DOI | https://dx.doi.org/10.17582/journal.sja/2021/37.3.884.892
Keywords | Ants taxonomy, Formicidae, Genus Lepisiota, New distributional records, Khyber Pakhtunkhwa

\section{Introduction}

A nts are widely distributed, universally known, dominant group of individuals, grouped in family Formicidae, superfamily Vespoidea and order Hymenoptera of class Insecta. Globally ants acquired major position as keystone species, comprising $30 \%$ of faunal biomass in terrestrial environment. They evolved as more diverse and ecologically rich group among social insects (Majer, 1985). They are separated from other hymenopterans by presence of single or double petioles between alitrunk and gaster. Furthermore, they are classified in 15,000 species placed in 296 genera and 16 subfamilies (Bolton, 1994). Among them 12,000 are specified (Bolton et al., 2006).

In geographical regions, Indo-Austalian region has large number of genera reported so far while African and Neotropical regions are more diverse and richer in endemic ant fauna than oriental and Nearctic region (Bolton, 1994). According to Bharti et al. (2016), about 828 species under 100 genera are reported only from India.

The tropical and continental forests have much more 
diversity of ant fauna. Roughly these areas were documented to have about 2200 species reported only from Asia (Schmid-Hempel, 1992). The diversity of ants lowers gradually with ecological factors like latitudes, altitudes and aridity (Brener and Ruggiero, 1994).

Pakistan, a very important ecological zone of the oriental region has the biodiversity estimate far from conclusive. On other hand, there are serious issues of soil erosion, water logging, deforestation, and threats to other habitats, which badly effect biodiversity of region (Baig and Al-Subaiee, 2009). Khyber Pakhtunkhwa, a province of Pakistan, known earlier for its geographical position as North-West Frontier Province, situated at $34^{\circ} 9526 \mathrm{~N}$ and $72^{\circ} 3311 \mathrm{E}$, covering $101,741 \mathrm{~km}^{2}$. It is known well for its rich biodiversity, variety of habitats, varied environmental conditions and geologic history. It is situated in north west region of country along the border of Afghanistan. Geographically, the region is divided into two zones. Its northern zone is snowy and extremely cold in winters while summers are quite pleasant with heavy rainfall. However, its southern zone is hot and arid in summers and cold and dry in winters with very less rainfall. Dera Ismail khan, part of southern zone is even considered as one of the hottest regions of South Asia. Its climate varies a lot for a region of this much size, having most of the climate types found in Pakistan. Its snowy peaks, lush green valleys and dry hot plains present an unusual beauty with enormous biodiversity of life forms and climate

Ants are one of the important keystone species, occupying key position in our ecosystem. Its role cannot be denied because of its active involvement in our daily life. They form important group of social insects; their social behavior is mirror image of human social behavior. They can occupy almost every region of our world, presenting massive variation in geographic and ecological distribution. Its conservation needs its comprehensive information about distribution and taxonomy. That's why current study was planned to explore the distribution and taxonomical identification of variety of ant specimens collected from geographically and ecologically rich, biodiverse region of Khyber Pakhtunkhwa Pakistan, a home of very impressive diversity of life forms.

\section{Materials and Methods}

\section{Area of study}

Current study was performed on worker caste of ants belonging to Family Formicidae collected from different areas of KP, Pakistan. Ants were collected throughout the year during their active season. A map is provided showing main divisions of $\mathrm{KP}$ which were focused for survey i.e., Charsadda, Nowshera, Dera Ismail Khan, Bannu, Kohat, Peshawar, Mardan, Hazara, and Malakand. Collection from hilly areas of Galyat, Chitral, Waziristan, Bajaur and Dir was also included for collection of ants.

\section{Methods of collection and identification}

Standard insect collection was done with the help of aspirators and hand-picking during day and night time from dense vegetation, bushes, shrubs, weeds, small and tall grasses, bases and tops of tree trunks, agricultural fields, inside houses, roadsides, river sides, crevices, and from carcasses. Collected specimen were killed with the help of cotton swab soaked in ethyl acetate. Dead specimens were then kept in $70 \%$ ethanol for long time preservation. Preserved specimens were cleaned with the help of benzene, to remove dust and other body waxes. The specimens were kept in $90 \%$ ethanol 24 hours before mounting them on point cards or pinning them in thorax. All the specimen were identified mainly with the help of (Bingham, 1903, The fauna of British India, including Ceylon and Burma. Hymenoptera, Vol. II. Ants and Cuckoowasps. Bolton (1995), Bharti (2011, 2012), Bharti and Akbar (2013), Bharti et al. (2013), Wachkoo and Bharti (2014), Bharti et al. (2016), Akbar et al. (2017), Bodlah et al. (2017), Rasheed et al. (2019, 2020, 2021) were followed for identification of the collected ant specimen.

\section{Equipment and software used}

Nikon SMZ 745T stereo zoom trinocular microscope mounted with camera Nikon DS F-i2 was used for the identification and taking images of specimens. Stacking of important characters was done using Helicon Focus version 6.2.2. Nikon DS F-i2 was used for accurate measurements of the specimen.

\section{Keys preparation}

Keys to the subfamilies and species collected form Khyber Pakhtunkhwa is prepared from the most easily observable characters.

\section{Tables and specimen preservation}

A table showing spatial distribution of each species is also provided. The entire identified specimens are kept in Insect Museum, Department of Zoology, Abdul 
Wali Khan University, Mardan. Additional specimens are deposited at Insect Museum, Department of Entomology, The University of Agriculture, Peshawar, Pakistan.

\section{Abbreviations used}

Following abbreviations are used in text;

\begin{tabular}{|c|c|c|c|}
\hline $\begin{array}{l}\text { Abbrevia- } \\
\text { tion used }\end{array}$ & Complete name & $\begin{array}{l}\text { Abbrevia- } \\
\text { tion used }\end{array}$ & $\begin{array}{l}\text { Complete } \\
\text { name }\end{array}$ \\
\hline $\mathrm{Bi}$ & Baragali & $\mathrm{Kt}$ & Kohat \\
\hline Bjr & Bajaur & $\mathrm{Lt}$ & Lakki Marwat \\
\hline $\mathrm{Br}$ & Buner & $\mathrm{Ma}$ & Mansehra \\
\hline $\mathrm{Bu}$ & Bannu & Mkd & Malakand \\
\hline $\mathrm{Ch}$ & Charsadda & $\mathrm{Mn}$ & Mardan \\
\hline Chl & Chitral & $\mathrm{Ni}$ & Nathiagali \\
\hline DIK & Dera Ismail Khan & Nrn & Naran \\
\hline Dir & Dir & Nsr & Nowshehra \\
\hline Gt & $\begin{array}{l}\text { Abdominal/ Gaster } \\
\text { segments }\end{array}$ & Pwr & Peshawar \\
\hline Kgn & Kaghan & $\mathrm{Sb}$ & Swabi \\
\hline Khr & Khanaspur & Sha & Shangla \\
\hline KP & Khyber Pakhtunkhwa & Wa & Wana \\
\hline $\mathrm{Kk}$ & Karak & & \\
\hline
\end{tabular}

\section{Results and Discussion}

In Indo-Pak, the only significant work was done by Bingham (1903). His work was followed and it is still followed for taxonomic work of Indo-Pak region. No comprehensive work has been done in this part of the world after Bingham. In recent era Bharti (2011, 2012), Bharti and Akbar (2013), Wachkoo and Bharti (2014), Bharti et al. (2016) and Akbar et al. (2017) has initiated work on Indian ants. In Pakistan, traces of work have been started by Umair et al. (2012), Usman et al. (2017), Rasheed et al. (2019, 2020, 2021), Lakho et al. (2019) but still lot of research is needed to perform comprehensive work on ants of Pakistan.

Studying importance of ants and availability of scarce information regarding its taxonomy, we were compelled to explore biodiversity of Khyber Pakhtunkhwa, Pakistan. This baseline study will be helpful in future ant's conservation programs.

In current study, we have reported only 4 subfamilies (Formicinae, Ponerinae, Amblyoponinae and Myrmicinae) with 10 genera. Among these genera, only Genus Lepisiota bearing 3 species and a subspecies new to the distributional records of KP and
Pakistan is discussed.

Key to the subfamilies of worker ants of Khyber Pakhtunkhwa is presented as follows.

Key to the subfamilies of family formicidae based on external morphology of workers caste, from Khyber Pakhtunkhwa, Pakistan

1. Eyes present 2

$1^{\prime}$. Eyes absent. Amblyoponinae

2. Body with a single node ......................... 3

2 '. Body with two nodes (petiole and post petiole) Myrmicinae

3. Abdomen with more or less marked constriction between basal two segments of abdomen; terminal end of abdomen with a rounded opening posteriorly (acidopore), acidopore with a sting and without a fringe of hairs surrounding it ........................................Ponerinae

3' Abdomen without any constriction between basal two segments of abdomen; terminal end of abdomen with a rounded opening posteriorly, acidopore nozzle shaped, without a sting and with or sometimes without a fringe of hairs surrounding it Formicinae

\section{Subfamily formicinae}

In current study, among 10 genera under the subfamily Formicinae have been encountered from various geographical locations of the province. Key to the species of genus Lepisiota under subfamily Formicinae of KP is given as follows.

\section{Genus Lepisiota Santschi (1926)}

- Lepisiota Santschi (1926a) PDF: 15 [as subgenus of Acantholepis]. Type-species: Plagiolepis rothneyi, by original designation.

- [Lepisiota first available replacement name for Acantholepis Mayr, 1861 (junior homonym of Acantholepis Kroyer, 1846: 98 (Pisces)), hence valid name of genus: Bolton, 1995b: 33.].

- Lepisiota in Formicinae, Plagiolepidini: Bolton, 1994: 51; Bolton, 2003 PDF: 23.

- [Lepisiota incorrectly as junior synonym of Acanthomyrmex: Brown (1973) and Snelling (1981). In both publications Acanthomyrmex is an error for Acantholepis.].

- Subgenera of Lepisiota: nominal plus Lepisiota (Baroniurbania): (Dietrich, 2004).

In current study, this genus comprises of 3 species encountered from different areas of KP. Key to the 
species of this genus is given as below.

Key to the ant species belonging to the worker caste of genus Lepisiota based on morphological identification from Khyber Pakbtunkbwa, Pakistan

1. Antennal scape remarkably long, extending posterior margin of head more than half the length of antennal scape................. frauenfeld $i$

$1^{\prime}$. Antennal scape not so long, extending posterior margin of head by not longer than one third its length 2

2. Node of pedicel with its upper lateral angles supported with short thick spines or teeth, pointing outwards, or node with emerginate upper part; abdomen apically pilose, head, thorax and abdomen smooth without any pilosity ............................................. simplex

2 '. Node of pedicel with its upper angles prevailed with fine, long, acute vertical spines; color and pilosity of head thorax and abdomen different .. 3

3. Abdomen purple, brown or black, without yellow markings ................................................ opaca

3'. Abdomen dull black, the gaster segment 1 above and in front brownish yellow. O. pulchella

\section{Lepisiota frauenfeldi Mayr (1855) (Plates 1-3)}

- Hypoclinea frauenfeldi Mayr (1855) PDF: 378 (w.) Yugoslavia. Palearctic.

- Roger, 1859 PDF: 243 (q.); Emery, 1878: 46 (m.); Wheeler and Wheeler, 1968 PDF: 209 (1.).

- Combination in Acantholepis: Mayr, 1861 PDF: 42; in Lepisiota: (Urbani et al., 1992).

- Senior synonym of Lepisiota frauenfeldi azerbeidzhanica, Lepisiota caucasica: (Arakelian, 1994).

- Bingham, 1903 PDF: 316; Santschi, 1917, PDF: 42; Tohmé, 1981 PDF: 1; Atanassov and Dlussky, 1992: 205.

Diagnostic characters: $L$. frauenfeldi can be separated from other species of the genus by the following characters; antennal scape extremely long, almost $1.5 \mathrm{x}$ longer than the posterior margin of apex of the head.

Material examined: $(\mathrm{n}=23 \not)$. Pakistan, KP., 3ఫ, Karak, 3576 18N, 3116 4E, 09.ix.2018, Najibullah. 3ซ, Wana, 3230 28N, 6956 88E, 14.ix.2018, Najibullah. 3ఫ్, Bannu, 3298 61N, 7060 41E, 09.ix.2018, Najibullah. 1ષ̛, Bara Gali, 3409 99N, 7334 99E, 24.vii.2017, Fahad and Najibullah. 2ซ, Nathiagali,
3406 66N, 7338 33E, 26.viii.2018, Najibullah. 2ఫ, Nizampur, $32.2433^{\circ} \mathrm{N}, 74.2619^{\circ} \mathrm{E}, 19.1 i i .2020$. Toheed Iqbal. 1૪, Mansehra, 3433 33N, 7319 99E, 21.vii.2018, Fahad and Usman. 1ఫ, Kalam (Gabral), 3552 50N, 7241 25E, 03.vii.2018, Fahad and Usman. 3ఫ, Lakki Marwat, 3225 08N, 7047 18E, 1-3.v.2019, Toheed Iqbal. 2ఫ, Sarai Naurang (Gandhi Chowk), 3270 13N, 7078 03E, 1-2.v.2019, Toheed Iqbal. 1ซ্,, Mardan, 3412 00N, 7203 10E, 27.iv.2019, Kiran and Marwa. 1४্, Dir Upper (Kumrat), 3556 10N, 7220 15E, 10.vii.2017, Fahad and Usman.

Distribution: The species is native to Palearctic region. It has also been reported from Algeria, Morocco, Azerbaijan, Iran, UAE, Bulgaria, Croatia, Greece, Italy, Malta, Spain, and Guam (Bolton, 2020).

Comments: This species was first reported by Mayr (1855) as Hypoclinae frauenfeldi. The species can be identified among other members of the genus Lepisiota by a long scape, almost $1.5 \mathrm{x}$ long, reaching behind the posterior margin of the head. It ranges in size from 2-3mm. Bingham (1903) reported it to be a variable species and marks some major differences with the species Acantholepis bipartite. Bolton (2020) reports 15 subspecies of this species. As in Pakistan, taxonomic work on Formicidae has not been so encouraging that we can rely on it, we therefore followed Bingham (1903) and Bolton (2020) for our identification. His work is still acceptable as it is such masterpiece that even after more than a century; his document is a source of identification in Indian subcontinent. The literature of Bolton (1994, 2003) is also helpful in removing confusion of synonyms. Moreover, the website of Bolton (2020) is also helpful in comparing the species photographs with the specimen. The website also provides access to the literature. From Pakistan this species has been reported before its creation by Bingham (1903). Umair et al. (2012) reported it from Rawalpindi district of Pakistan with the name Acantholepis frauenfeldi under subfamily Camponotinae, which shows that he strictly followed Bingham (1903). From KP this species is reported from district Charsadda and Swabi by Rasheed et al. (2020, 2021), respectively. Current research provides new distributional records for KP and Pakistan with detailed description, images and localities. As mentioned in Table 1, this species has been reported from Wana, Karak, Lakki Marwat, Mardan, Peshawar, Nowshera, 
Table 1: Spatial distribution of genus Lepisiota species and sub-species collected from different areas of Khyber Pakbtunkbwa, Pakistan during 2017-2020.

Species Pwr Mn Ch Nsr Sb Chl Ma Kgn Nrn Bi Ni Swt Khr Dir Sha Bjr Kt Bu Kk Lt Br Wa DIK Mkd
L. frauenfeldi
L. simplex
L. opaca
L. o. pulchella

$69^{\circ} 0^{\prime} 0^{\prime \prime} \mathrm{E} \quad 70^{\circ} 0^{\prime} 0^{\prime \prime} \mathrm{E} \quad 71^{\circ} 0^{\prime} 0^{\prime \prime} \mathrm{E} \quad 72^{\circ} 0^{\prime} 0^{\prime \prime} \mathrm{E} \quad 73^{\circ} 0^{\prime} 0^{\prime \prime} \mathrm{E} \quad 74^{\circ} 0^{\prime} 0^{\prime \prime} \mathrm{E}$

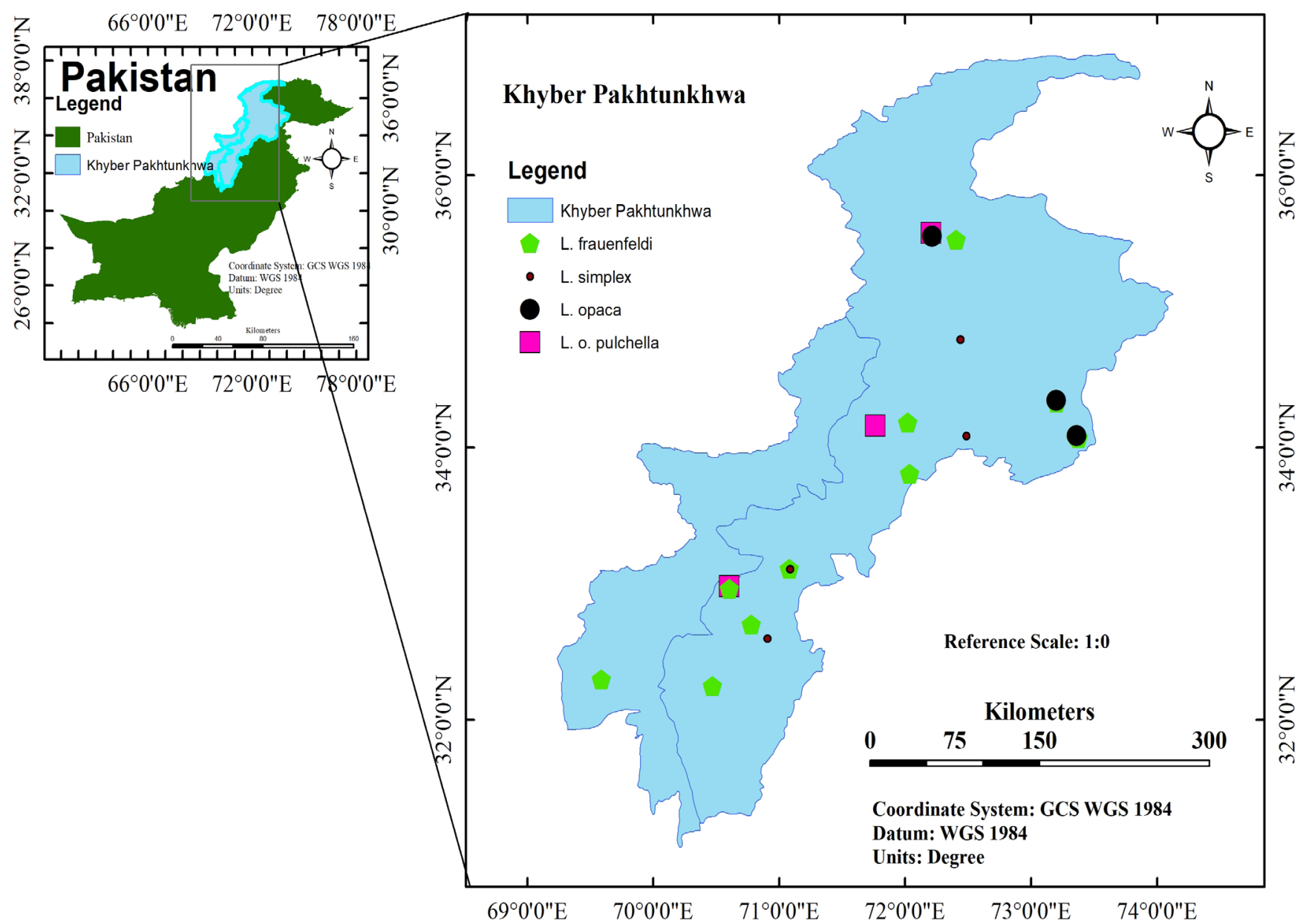

Figure 1: Map of Khyber Pakhtunkhwa, Pakistan, showing spatial distribution of different worker species of genus Lepisiota.

Baragali and Nathiagali in current studies which show that the species is spread over a wide area of KP. Spatial distribution of the species is given in map provided in Figure 1.

\section{Lepisiota simplex Forel (1892) Plates (4-6)}

- Acantholepis simplex Forel (1892a) PDF: 43 (diagnosis in key) (w.) Somalia. Afrotropic. Primary type information: Somalia, coll. Keller; CASENT0909878; MHNG

- Combination in Lepisiota: Bolton, 1995b: 228. Forel, 1892e PDF: 350 (q.m.).

- Status as species: Bingham, 1903 PDF: 317; Forel, 1910 PDF: 449; Forel, 1916 PDF: 438;
Santschi, 1914 PDF: 378; Sharaf et al., 2016 10.1080/00222933.2016.1180722 PDF: 1885.

- as subspecies of Lepisiota capensis: Forel, 1907i PDF: 86 (footnote); Arnold, 1920a PDF: 572; Wheeler, 1922: 937.

Diagnostic characters: The species differs from other members of the genus by characters mentioned as follows; overall body smooth without pilosity, except abdomen apically.

Material examined: $(\mathrm{n}=7 \Varangle)$. Pakistan: KP.; 1ఫฺ, Karak, 3576 18N, 3116 4E, 09.ix.2018, Najibullah. 4ఫ, Kalam (Gabral), 3552 50N, 7241 25E, 03.vii.2018, 
Fahad and Usman. 2ఫ, Swabi, 3411 66N, 7246 66E, 10.x.2018, Najibullah.

Distribution: Lesotho, Somalia (Africa), Saudi Arabia (Asia) (Bolton, 2020).

Comments: The species can be identified by entirely smooth body, apical margin of the abdomen pilose. The species was first reported by Forel (1892) from Afro tropical region. It is assumed to be sub species of L. capensis by Forel (1907), Arnold (1920), Wheeler (1922) after synonymizing it from Acantholepis to Lepisiota by Bolton (1995). The species is distributed in Africa and recently Sharaf et al. (2016) reported this species with a new status from Saudi Arabia. This species is collected with aspirator from Swabi, Swat, and Karak areas of KP. It shows that the species is distributed in plain, humid, warm and hilly areas of KP. Current species adds new distributional records to the knowledge of Formicidae of KP and Pakistan.

\section{Lepisiota opaca Forel (1892) (Plates 7-9)}

- Acantholepis opaca Forel (1892a) PDF: 43 (diagnosis in key) (w.) India. Indomalaya.

- Combination in Lepisiota: Xu, 1994: 235. Bingham, 1903 PDF: 318.

Diagnostic characters: Lepisiota opaca can be differentiated from other members of the genus Lepisiota by having purplish brown or black abdomen with yellowish markings (Bingham, 1903).

Material examined: $(\mathrm{n}=15 \not{q})$. Pakistan, KP., 1ఫ, Bara Gali, 3409 99N, 7334 99E, 24.vii.2017, Fahad and Najeeb. 9ఫ, Dir Upper (Kumrat), 3556 10N, 7220 15E, 10.vii.2017, Fahad and Usman. 5ซ, Mansehra, 3433 33N, 73 19 99E, 21.vii.2018, Fahad and Usman.

Distribution: China, India, Indomalaya (Bolton, 2020).

Comments: Morphologically the species differentiated from other members of the genus by having purplish brown or black abdomen with yellowish markings. According to Bingham (1903) species has been separated from very closely related $L$. pulchella by above mentioned character as well as the thorax is broader than L. pulchella, and region of mesonotum not so strongly constricted. This species was first reported by Forel (1892) under genus Acantholepis. Later the genus was replaced by Lepisiota, and hence the valid name till date remains $L$. opaca. This species seems to be native of Indian subcontinent as it is not reported elsewhere as mentioned above. Currently this species is encountered with the help of aspirator and hand picking with the help of forceps from hilly region of Hazara division (Mansehra and Baragali) and Gabral area of Swat division which meets Kumrat region of Upper Dir across the mountains. Bingham (1903), Bolton (1995) were followed for identification of genus and species. Additionally, species were confirmed by comparing with images provided by Bolton (2020).

\section{Lepisiota opaca pulchella (Forel 1892) Plates (10-12)}

- Acantholepis opaca r. pulchella Forel 1892a PDF: 43 (diagnosis in key) (w.) India (Maharashtra).

- Combination in Lepisiota: Bolton, 1995b: 228.

- Subspecies of Lepisiota opaca: Dalla Torre, 1893: 172; Forel, 1894: 414; Emery, 1925 PDF: 27; Chapman and Capco, 1951: 210; Bolton, 1995b: 228.

- Status as species: Bingham, 1903 PDF: 318; Wu, and Wang, 1995: 129; Zhou, 2001: 168.

Diagnostic characters: L. o. pulchella is sub-species of $L$. opaca but can be differentiated from it through the following characters; abdomen dull black, antero-dorsally the abdomen $\left(\mathrm{Gt}_{1}\right)$ brownish yellow; pronotum narrow; mesonotum with shallow or weak constriction anteriorly with pronotum.

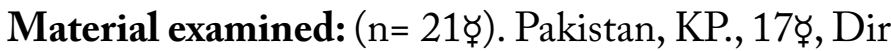
Upper (Kumrat), 3556 10N, 7220 15E, 10.vii.2017, Fahad and Usman. 1ષ̛, Bannu, 3298 61N, 7060 41E, 09.ix.2018, Najibullah. 3ఫ్, Charsadda, 3414 40N, 74 73 17E, 01.v.2018, Najibullah.

Distribution: India (Bolton, 2020).

Comments: Bingham (1903) in his key separated this species from similar in appearance with minute characters. In description of this species, he mentions its resemblance with $L$. opaca, but then explains the differences as well. Bolton (1995) synonymized this species under Lepisiota, which was Acantholepis earlier. This species is presented as sub-species of $L$. opaca. The species is reported only from India. Current study confirms its existence from hilly as well as plain areas of Khyber Pakhtunkhwa province of Pakistan. This sub-species is reported for the first time not only from KP but also from Pakistan. 


\section{Acknowledgements}

Authors are highly indebted to Prof. Dr. Sajjad Ahmad, Department of Entomology, The University of Agriculture, Peshawar, for providing us lab space. Authors also thankful to Dr. Himender Bharti, Head Department of Zoology and Environment Sciences, Punjabi University Patiala, India for technical guidance and helping in identification.

\section{Novelty Statement}

The baseline study was initiated in Khyber Pakhtunkhwa Pakistan to record and enlist, species of genus Lepisiota. In this research, three species were reported and one subspecies as new distributional records from different areas of Northwestern part of Pakistan.

\section{Author's Contribution}

Kiran Shahjeer: Principal author who conducted the research and wrote the article.

Gauhar Rehman and Khurshaid Khan: Supervised the research.

Toheed Iqbal: Reviewed and improved the article.

\section{Conflict of interest}

The authors have declared no conflict of interest.

\section{References}

Akbar, S.A., H. Bharti and A.A. Wachkoo. 2017. Discovery of remarkable new ant species of the genus pseudolasius emery (Hymenoptera: Formicidae) from western ghats of India. Sociobiology, 64: 133-137. https://doi. org/10.13102/sociobiology.v64i2.1188

Arakelian, G.R. 1994. Fauna of the Republic of Armenia. Hymenopterous insects. Ants (Formicidae). Gitutium, Erevan, pp. 153.

Arnold, G., 1920. A monograph of the Formicidae of South Africa. Part IV. Myrmicinae, trustees of the South African Museum.

Atanassov, N., and G.M. Dlussky. 1992. Fauna of Bulgaria. Hymenoptera, Formicidae. [In Bulgarian.]. Fauna na Bûlgariya 22:1-310.

Baig, M.B. and F.S. A1-Subaiee. 2009. Biodiversity in Pakistan: Key issues. Biodiversity, 10: 20-29. https://doi.org/10.1080/14888386.2009.9712 858
Bharti, H. and S.A. Akbar. 2013. Taxonomic studies on the ant genus Cerapachys Smith (Hymenoptera, Formicidae) from India. ZooKeys, pp. 79. https://doi.org/10.3897/ zookeys.336.5719

Bharti, H., 2011. List of Indian ants (Hymenoptera: Formicidae). Halteres, 3: 79-87.

Bharti, H., 2012. Two new species of the genus Myrmica (Hymenoptera: Formicidae: Myrmicinae) from the Himalaya. Tijdschrift voor Entomologie, 155: 9-14. https://doi. org/10.1163/004074912X631742

Bharti, H., B. Guénard, M. Bharti and E.P. Economo. 2016. An updated checklist of the ants of India with their specific distributions in Indian states (Hymenoptera, Formicidae). ZooKeys, pp. 1. https://doi.org/10.3897/ zookeys.551.6767

Bharti, H., Y.P. Sharma, M. Bharti and M. Pfeiffer. 2013. Ant species richness, endemicity and functional groups, along an elevational gradient in the Himalayas. Asian Myrmecol., 5: 79-101. Bingham, C., 1903. The fauna of British India, including Ceylon and Burma. Hymenoptera, Vol. II. Ants and Cuckoo-wasps. The fauna of British India, including Ceylon and Burma. Hymenoptera, Vol. II. Ants and Cuckoo-wasps. Bodlah, I., M.A. Bodlah, M.T. Rasheed, T. Akhter, A. Aihetasham and M. Yousaf. 2017.New distributional records of Tetraponera Rufonigra (Jerdon) from Gilgit Baltistan. Asian J. Agric. Biol., 5: 1-6.

Bolton, B., 1994. Identification guide to the ant genera of the world, vol. null.

Bolton, B., 1995. A new general catalogue of the ants of the world.

Bolton, B., 2003. Synopsis and classification of Formicidae, American Entomological Institute.

Bolton, B., G. Alpert, P.S. Ward and P. Naskrecki. 2006. Bolton's Catalogue of Ants of the World. Massachusetts, Harvard University Press (CDROM).

Bolton, B., 2020. An online catalog of the ants of the world; AntWeb. Version 8.28.4. California Academy of Science, online at https://www. antweb.org. Accessed 5 May 2020.

Brener, A.G.F. and A. Ruggiero. 1994. Leafcutting ants (Atta and Acromyrmex) inhabiting Argentina: patterns in species richness and geographical range sizes. J. Biogeogr., pp. 391399. https://doi.org/10.2307/2845757 
Brown, Jr, W. L. 1973. A comparison of the Hylean and Congo-West African rain forest ant faunas. In: Toropical forest ecosystems in Africa and Sauth America: A comparative review, Smithsonian Institute Press, Washington D.C. pp. 161-185.

Chapman, J.W. and S.R. Capco. 1951. Check list of the ants (Hymenoptera: Formicidae) of Asia. Monographs of the Institute of Science and Technology, Manila. 1:1-327.

Dietrich, C.O. 2004. Taxonomische Beiträge zur Myrmekofauna Jordaniens (Hymenoptera: Formicidae). na.

Emery, C. 1925d. Hymenoptera. Fam. Formicidae. Subfam. Formicinae. Genera Insectorum 183:1302.

Forel, A., 1892. Liste der aus dem Somaliland von Hrn. Prof. Dr. Conr. Keller aus der Expedition des Prinzen Ruspoli im August und September 1891 zurückgebrachten Ameisen. Mitteilungen der Schweizerischen Entomologischen Gesellschaft, 8: 349-354.

Forel, A., 1907. Reise in Ostafrika 2: 75.

Forel,A.1910. Note sur quelques fourmis d'Afrique. Annal. Soc. Entomol. Belgique, 54:421-458.

Forel, A. 1916. Fourmis du Congo et d'autres provenances récoltées par MM. Hermann Kohl, Luja, Mayné, etc. Rev. Suisse Zool., 24:397-460.

Lakho,G.,I.Khatri and Z.Ahmed.2019.Taxonomic History of Formicidae Hymenoptera Pakistan. Sindh Univ. Res. J. (Sci. Ser.), 51: 713-720. https://doi.org/10.26692/SURJ/2019.12.113

Majer, J., 1985. Recolonization by ants of rehabilitated mineral sand mines on North Stradbroke Island, Queensland, with particular reference to seed removal. Aust. J. Ecol. 10: 3148. https://doi.org/10.1111/j.1442-9993.1985. tb00861.x

Mayr, G.L., 1855. Formicina austriaca: Beschreibung der bisher im österreichischen Kaiserstaate aufgefundenen Ameisen, nebst Hinzufügung jener in Deutschland, in der Schweiz und in Italien vorkommenden Arten, Druck von Karl Ueberreuter.

Rasheed, M.T., I. Bodlah, A.G.E. Fareen, A.A. Wachkoo, X. Huang and S.A. Akbar. 2019. A checklist of ants (Hymenoptera: Formicidae) in Pakistan. Sociobiology, 66: 426-439. https:// doi.org/10.13102/sociobiology.v66i3.4330

Rasheed, S., M. Ali, F. Zaidi and S. Noreen. 2021. Diversity of ants (Hymenoptera: Formicidae) in residential area of Tarbela, Swabi: New records from Pakistan. J. Animal Plant Sci., pp. 31. https://doi.org/10.36899/JAPS.2021.2.0250

Rasheed, S.B., A. Yar, F. Zaidi and Q. Jamal. 2020. The diversity of ants (Hymenoptera:Formicidae) in District Charsadda, Khyber Pakhtunkhwa: New Reports from Pakistan. Pak. J. Zool., 52: 1363-1370. https://doi.org/10.17582/journal. pjz/20180916170913

Santschi, F. 1914. Formicides from West and Southern Africa from the trip of Professor F. Silvestri. Bollettino del Laboratorio di Zoologia Generale e Agraria della Reale Scuola Superiore d'Agricoltura. Portici 8: 309-385.

Santschi, F., 1926. Trois notes myrmécologiques. In: Annales de la Société Entomologique de France, 1926. pp. 13-28.

Schmid-Hempel, P., 1992. B. Hölldobler, EO Wilson (1990): The Ants Springer, Berlin, 732 pp.DM 198.J. Evolut. Biol., 5: 169-171. https:// doi.org/10.1046/j.1420-9101.1992.5010169.x

Sharaf, M.R., J. Monks, A. Polaszek and A.S. Aldawood. 2016. A remarkable new species of the genus Lepisiota Santschi (Hymenoptera: Formicidae) from Oman and the United Arab Emirates with a key to the Arabian species. J. Nat. Hist., 50: 1875-1887. https://doi.org/10.1 080/00222933.2016.1180722

Snelling, R.R. 1981. Systematics of social Hymenoptera. Social Insects, 2: 369-453.

Tohmé, H. 1981. Écologie et biologie de la reproduction de la fourmi Acantholepis frauenfeldi, Mayr (Hymenoptera, Formicoïdae, Formicinae).

Umair, M., A. Zia, M. Naeem, and M.T. Chaudhry. 2012. Species composition of ants (Hymenoptera: Formicidae) in Potohar plateau of Punjab province, Pakistan. Pakistan J. Zool., 44: 699-705.

Urbani, C.B., B. Bolton and P.S. Ward. 1992. The internal phylogeny of ants (Hymenoptera: Formicidae). Syst. Entomol., 17(4): 301-329.

Usman, K., S. Gul, H.U. Rehman, K. Pervaiz, H. Khan, S. Aslam, J. Hanif, S. Manzoor, T. Maqbool and S. Gul. 2017. Field observations on the incidence of Ants fauna (Hymenoptera) of Karak Khyber Pakhtunkhwa, Pakistan.

Wachkoo, A.A., and H. Bharti. 2014. Two new species of Pseudolasius (Hymenoptera: Formicidae) from India. Sociobiology, 61: 274280. https://doi.org/10.13102/sociobiology. 
v61i3.274-280

Wheeler, W.M., 1922. Ants of the American Museum Congo expedition.

Wheeler, G.C. and J. Wheeler. 1968. The ant larvae of the subfamily Formicinae (Hymenoptera; Formicidae): supplement. Ann. Entomol. Soc. Am., 61(1): 205-222.

Wu, J. and C. Wang. 1995. The ants of China. [In Chinese.]. Beijing: China Forestry Publishing House, $x+214$ pp.
Xu, Z. 1994. A taxonomic study of the ant genus Lepisiota Santschi from southwestern China (Hymenoptera Formicidae Formicinae). [In Chinese.]. J. Southwest Forest. Coll. 14:232237.

Zhou, S.Y. 2001. A new species of the ant genus Liometopum Mayr from Guangxi, China. (Hymenoptera: Formicidae). Acta Zootaxon. Sin., 26:557-559. 